\title{
ILLUSTRATIONS ACKNOWLEDGEMENTS
}

The Publisher wishes to thank Wendy Watriss for permission to reproduce the three photographs of the Vietnam Veterans Memorial in Chapter 28; the Imperial War Museum for permission to reproduce John Singer Sargent's Gassed, Percy Wyndham Lewis's A Battery Shelled, Paul Nash's The Mule Track, We are Making a New World and Battle of Britain, Stanley Spencer's Travoys Arriving, William Orpen's Blown Up, Elsie Hewland's A Nursery-School for War Workers' Children; and the British Museum for the right to reproduce Henry Moore's First Shelter Sketchbook page 26. It has made every effort to contact the copyright holders for Louis Raemaekers's The Gas Fiend and Slow Asphyxiation and we will be happy to acknowledge them appropriately if they contact us. 